\title{
Protagonista da amamentação ou instrumento da política de saúde infantil?: a enunciação da mulher nos materiais oficiais de promoção $e$ orientação ao aleitamento materno
}

\author{
Protagonist of breastfeeding or an instrument of child health policy?: \\ the enunciation of women in official promotional and guidance \\ materials to breastfeeding
}

\author{
Irene Rocha Kalil \\ Fundação Oswaldo Cruz. Instituto Nacional de Saúde da Mulher, \\ da Criança e do Adolescente Fernandes Figueira. Rio de Janeiro, \\ RJ, Brasil. \\ E-mail: irenekaliløgmail.com \\ Adriana Cavalcanti de Aguiar \\ Fundação Oswaldo Cruz. Instituto de Comunicação e Informação \\ Científica e Tecnológica em Saúde. Rio de Janeiro, RJ, Brasil. \\ Universidade do Estado do Rio de Janeiro. Instituto de Medicina \\ Social. Rio de Janeiro, RJ, Brasil. \\ E-mail: adriana.aguiarœpost.harvard.edu
}

\section{Correspondência}

Irene Rocha Kalil

Avenida Rui Barbosa, 716, 6 andar, Prédio Administrativo, Flamengo.

Rio de Janeiro, RJ, Brasil. CEP 22250-020.

\section{Resumo}

Este artigo analisa materiais de promoção e orientação ao aleitamento materno recentes, produzidos pelo Ministério da Saúde (MS) brasileiro, identificando aproximações e diferenças entre os discursos voltados a gestantes e lactantes e aqueles dirigidos a profissionais de saúde em relação aos sentidos propostos acerca da mulher. Com base na teoria da enunciação, identificamos que, mesmo permanecendo o eu ou sujeito da enunciação dos discursos analisados, identificado como MS, persistem distinções significativas na abordagem da mulher. Nos manuais para profissionais de saúde, nos quais a mulher é o sujeito sobre quem se fala, é mais comum ela aparecer representada como indivíduo dotado de subjetividade e protagonista do processo. Por outro lado, de modo geral, as mulheres são tratadas de forma objetificada nos materiais voltados a elas mesmas, o que se revela por meio de linguagem normativa e imperativa que as configura como instrumento da política oficial de saúde infantil. Defendemos que compreender como o objeto de que se fala é constituído por/nesses discursos, assim como desvelar como neles se constroem as posições de sujeito e relações de poder, possibilita-nos problematizar essa comunicação que, de modo geral, negligencia as experiências e expectativas da mãe no processo de amamentação.

Palavras-chave: Aleitamento Materno; Saúde da Criança; Comportamento Materno; Materiais Educativos e de Divulgação; Comunicação em Saúde. 


\section{Abstract}

This article examines recent promotion and guidance materials to breastfeeding produced by the Brazilian Ministry of Health, identifying similarities and differences between the discourses aimed at pregnant and lactating women, and those directed to health professionals in relation to the proposed meanings about women. Based on the theory of enunciation, we identified that, while the self or subject of enunciation is still present in the analyzed discourse (identified as Brazilian Ministry of Health), significant distinctions persist in the approach of the women's role. In manuals for health professionals, in which the woman is the subject of whom it talks about, she is commonly represented as an individual with subjectivity who is the protagonist of the process. On the other hand, in materials aimed at women, we observed that, in general, they are treated in an objectified way, revealed through a normative and imperative language, which qualifies them as an instrument of the official policy for child's health. We argue that understanding how the object spoken is created by/in these discourses, unveiling how positions and power relations are constructed in them, enables us to discuss this communication that generally has neglected the experiences and expectations of mothers in breastfeeding. Keywords: Breastfeeding; Child Health; Maternal Behavior; Educational and Promotional Materials; Health Communication.

\section{Introdução}

Ao longo das últimas duas décadas, o Ministério da Saúde (MS) brasileiro intensificou a produção de materiais de educação e informação em saúde voltados à temática do aleitamento materno. Somente entre 2007 e 2010, o órgão produziu um volume significativo de documentos oficiais sobre o tema. Foram mais de dez publicações (entre cartilhas, guias, manuais, cadernetas e relatórios de pesquisas), além de folders, cartazes e vídeos relacionados ao aleitamento materno e à doação do leite humano. Também participou da elaboração de capítulos de livros e artigos científicos, deixando, inclusive, diversas publicações em andamento (BRASIL, 2011), o que revela a importância crescente que a informação e a comunicação têm adquirido no âmbito da saúde da criança em nosso país.

Tal importância se materializa na forma de documentos dirigidos a distintos públicos, que, segundo Frohmann (2008), têm, assim como os enunciados para Foucault (200o), o poder de "afetar ou criar sentidos” (p. 22). Verón (2004) argumenta, por sua vez, que uma mensagem não produz automaticamente um único sentido, mas que todo discurso desenha, no âmbito da sua produção, "um campo de efeitos de sentido" (p. 216) possíveis a respeito de algo ou algum aspecto do nosso estar no mundo, buscando estabilizar, ainda que só momentaneamente, sua significação. Para o autor, tal efeito só se constitui, de fato, no âmbito da recepção do discurso e de seu reconhecimento pelo interlocutor.

Desse modo, entendemos que, ao empreender esforços para difundir o discurso oficial acerca do tema, seja em campanhas dirigidas à população, publicações de orientação para profissionais ou livros e periódicos científicos, o MS, aqui entendido como emissor ou sujeito da enunciação, visa estabilizar os sentidos sociais sobre o aleitamento materno, destacando aqueles que estão de acordo com o que preconiza o Estado brasileiro, bem como seus parceiros: Sociedade Brasileira de Pediatria, Organização Mundial da Saúde, Unicef e outros organismos nacionais e internacionais que atuam em prol da causa.

Para a teoria da enunciação, como apropriada por Benveniste (1989) e Pinto (1994), aquele que fala 
constitui não apenas a si mesmo como sujeito falante ou locutor, mas também "implanta o outro diante de si” (Benveniste, 1989, p. 84). Ou seja, "toda enunciação é, explícita ou implicitamente, uma alocução, ela postula um alocutário" (Benveniste, 1989, p. 84). De acordo com esse referencial, portanto, ao proferir discursos sobre amamentação, o MS não só constitui o objeto de que fala - construindo, reforçando, enfraquecendo ou apagando sentidos sobre ele -, como também sua própria posição como locutor, o eu ou sujeito da enunciação (Benveniste, 1989); e a posição do seu receptor, o tu ou sujeito falado (Pinto, 1994).

O que em geral caracteriza a enunciação é a acentuação da relação discursiva com o parceiro, seja este real ou imaginado, individual ou coletivo. Esta característica coloca necessariamente o que se pode denominar o quadro figurativo da enunciação. Como forma de discurso, a enunciação coloca duas "figuras" igualmente necessárias, uma, origem, a outra, fim da enunciação. É a estrutura do diálogo. Duas figuras na posição de parceiros são alternativamente protagonistas da enunciação. Este quadro é dado necessariamente com a definição da enunciação. (Benveniste, 1989, p. 87, grifos no original)

No caso dos materiais de promoção ou orientação ao aleitamento materno analisados neste trabalho, o diálogo não se dá de forma efetiva por ser o receptor, como define Benveniste (1989), um parceiro imaginado. Isso não impede que esteja dado o quadro da enunciação de duas figuras, uma como origem e outra como fim desse processo de comunicação ou de proposição de sentidos sobre o tema abordado. Na opinião de Pinto (1994), o emissor do enunciado pode, por meio de determinadas operações, desde "criar universos de referência a serem compartilhados com o receptor" (p. 28) até "criar e/ou reproduzir, pelo exercício da linguagem, relações de poder entre emissor e receptor” (p.29).

Também para Verón (2004), um discurso desenha "um campo de efeitos possíveis" (p. 83) a partir do funcionamento da enunciação, que diz respeito "não ao que é dito, mas ao dizer e suas modalidades, os modos de dizer" (p. 216, grifos no original). Segundo o autor, o dispositivo da enunciação comportaria a imagem do enunciador, a imagem daquele a quem o discurso é endereçado, chamado de destinatário, e a relação entre enunciador e destinatário, "que é proposta no e pelo discurso" (p. 218, grifo no original). Por meio desse dispositivo, o emissor busca construir, estabilizar ou contrapor sentidos sobre um determinado tema, sentidos a serem compartilhados entre ele e o(s) receptor(es) do discurso, assim como estabelecer ou fortalecer laços de poder entre esses dois polos da comunicação, hierarquizando uma relação que acontece na esfera discursiva e, paralelamente, na social.

Inspirados pelas considerações desses autores sobre os dispositivos que, por meio dos discursos, permitem constituir objetos e posições de sujeito na comunicação e estabelecer relações de poder entre interlocutores, interessa-nos investigar como os discursos oficiais de aleitamento materno brasileiros têm procurado construir sentidos sobre a mulher nas duas posições distintas que ocupa: como objeto do enunciado (ou sujeito sobre quem se fala) nos materiais de orientação voltados aos profissionais de saúde; ou como sujeito falado, ou seja, receptor imaginado dos materiais destinados à população.

Utilizamos, particularmente, a categoria analítica nomeada por Pinto (1994) de modalização da enunciação, caracterizada por operações enunciativas que visam alcançar o objetivo de "projetar o tipo de interação que [o emissor] deseja estabelecer com o receptor e, por seu intermédio, sobre o mundo" (p. 81). Segundo o autor, existem seis tipos de modalidades: declarativa, representativa, declarativa-representativa, expressiva, compromissiva e diretivas, e pudemos identificar, nos textos analisados, exemplos de enunciados que puderam ser classificados a partir de algumas dessas modalidades.

Para fins da análise proposta, selecionamos, em agosto de 2013, entre as quase 40 publicações referentes à Coordenação-Geral de Saúde da Criança e Aleitamento Materno (então Área Técnica de Saúde da Criança e Aleitamento Materno - ATSCAM) disponíveis no portal do MS na internet, materiais que abordavam, especificamente, a temática da amamentação numa perspectiva menos técnica e mais conceitual: a Cartilha para a mãe trabalhadora que amamenta (BRASIL, 2010) e cinco cartazes de campanhas recentes da Semana Mundial da Ama- 
mentação (SMAM) dos anos de 2009, 2010, 2011, 2012 e 2013, voltados às próprias mulheres e à sociedade em geral; e quatro materiais destinados à formação de profissionais de saúde - Rede Amamenta Brasil: caderno do tutor (BRASIL, 2009a); Saúde da criança: nutrição infantil: aleitamento materno e alimentação complementar (BRASIL, 2009b); Iniciativa Hospital Amigo da Criança Módulo 3: promovendo e incentivando a amamentação em um hospital amigo da criança - curso de 20 horas para equipes de maternidade (Unicef; OMS, 2008); e Álbum seriado: promovendo o aleitamento materno (BRASIL; Unicef, 2007).

Embora o penúltimo material citado (Unicef; OMS, 2008) tenha sido adaptado pelo Ministério da Saúde de publicação original da OMS e Unicef, e o último (BRASIL; Unicef, 2007) seja uma publicação em parceria com organização internacional, entendemos que o Ministério da Saúde assume o discurso como seu, incorporando-o à política pública nacional de aleitamento materno. Consideramos, portanto, que, nesses casos, o órgão também pode ser definido como sujeito da enunciação.

\section{Um sujeito sobre quem se fala}

Os materiais analisados dirigidos aos profissionais de saúde têm como objetivo orientá-los sobre como atingir "uma alimentação ótima para as crianças pequenas" (BRASIL, 2009a, p. 7), recomendando-se às mulheres que amamentem seus bebês exclusivamente nos primeiros seis meses de vida e continuem amamentando, com alimentação complementar "apropriada", até os 2 anos de idade ou mais. Para o documento Rede Amamenta Brasil: caderno do tutor (BRASIL, 2009a), os profissionais de saúde que assistem a mulher que amamenta, sua família e a comunidade na qual está inserida devem possuir competências que incluam o conhecimento "dos aspectos históricos, sociais, culturais e biológicos da amamentação” (p.13).

Além disso, ele deve ter habilidade científica, técnica, política e de relacionamento para assistir, além desta mulher, também seu companheiro, filhos, família e comunidade, reunindo os diferentes segmentos que compõem a extensa rede sociobiológica do AM [Aleitamento Materno]. (Brasil, 2009a, p.13, grifos nossos)
"Auxiliar as mulheres, seus filhos e suas famílias para o sucesso da amamentação" é o objetivo último dos materiais destinados à formação dos profissionais da atenção à saúde. O Álbum Seriado: Promovendo o Aleitamento Materno (BRASIL; Unicef, 2007) trata de temas como as vantagens do aleitamento materno para o bebê, a mãe, o pai e a família; formas de preparação da gestante para amamentar ainda durante o pré-natal; a superação dos problemas mais frequentes relacionados à amamentação, como fissuras, mastite e outras dificuldades; a legislação brasileira de proteção à amamentação; entre outros. 0 material da Unicef e da Organização Mundial de Saúde (2008), por sua vez, "pode ser usado para fortalecer o conhecimento e a capacitação dessas equipes no sentido de uma boa implementação dos Dez Passos para o Sucesso do Aleitamento Materno" nas unidades de saúde credenciadas, favorecendo o aleitamento materno antes e depois da alta hospitalar.

Em geral, tais materiais já apontam uma visão ampliada da amamentação, compreendendo-a como "híbrido natureza-cultura" (Almeida, 1999) e estendendo-a "para além de suas determinações hormonais e fisiológicas" (BRASIL, 2009a, p. 88), e a mulher começa a ser retratada como protagonista do processo. Também aparecem, ainda que de forma superficial, as possíveis relações entre a amamentação e o estabelecimento de uma relação intersubjetiva da mulher com o bebê, tratando da contribuição do ato de amamentar para promoção e fortalecimento do vínculo entre mãe e filho(a) (BRASIL, 2009b; BRASIL; Unicef, 2007), e a importância de o profissional levar em consideração os contextos sociocultural e familiar da mulher que amamenta (BRASIL, 2009a, 2009b).

Exemplos disso são encontrados no caderno produzido para Equipes de Saúde da Família (BRASIL, 2009b), que caracteriza a amamentação como "a mais sábia estratégia natural de vínculo, afeto, proteção e nutrição para a criança” (p. 9), um processo que, além de nutrir a criança, "envolve interação profunda entre mãe e filho, com repercussões no estado nutricional da criança, [...] no seu desenvolvimento cognitivo e emocional, além de ter implicações na saúde física e psíquica da mãe” 
(BRASIL, 2009b, p.11, grifos nossos). A publicação considera, ainda, a importância de os profissionais de saúde serem sensíveis aos contextos em que ocorre a amamentação e entenderem a mulher como protagonista do processo de amamentar, "valorizando-a, escutando-a e empoderando-a" (p. 11, grifo nosso).

No material do curso voltado a equipes de hospitais credenciados na Iniciativa Hospital Amigo da Criança (Unicef; OMS, 2008) há uma seção específica que trata das habilidades de comunicação necessárias aos profissionais que atuam na atenção à gestante e à mulher que acabou de dar à luz na maternidade. Eles devem ser capazes de fornecer informações, mas também de ouvir as mulheres atendidas, que são dotadas de subjetividade, de suas próprias crenças e cultura.

Muitas vezes, profissionais de saúde são treinados para procurar problemas e resolvê-los. Uma boa comunicação significa que existe respeito pelos pensamentos, pelas crenças e pela cultura das mulheres. Isso quer dizer que você não vai dizer a uma pessoa o que acha que deve ser feito ou forçar uma mulher a agir de determinada forma. (Unicef; OMS, 2008, p. 46, grifos nossos)

0 tratamento dado à mulher, no entanto, não se mantém homogêneo em todos os materiais e nem mesmo nos discursos de um mesmo material. O próprio documento destinado à Atenção Básica, ao abordar o desmame, reconhece que, na espécie humana, este não está relacionado somente a fatores "genéticos" e "instintivos", sendo fortemente influenciado por fatores socioculturais, mas defende o que chama de "desmame natural", aquele que ocorreria "naturalmente, na medida em que a criança vai adquirindo competências para tal" (BRASIL, 2009b, p. 63). "A mãe também participa ativamente no processo", afirma o documento, sugerindo passos à criança, verdadeira protagonista do desmame, quando esta já estiver "pronta" a aceitá-los (p. 64, grifo nosso).

Ainda que afirme, em diversos trechos, o protagonismo da mulher e a necessidade de os profissionais de saúde estarem atentos a seus contextos e anseios, o mesmo material (BRASIL, 20ogb) faz orientações como: "A mãe deve ser orientada a responder prontamente às necessidades do seu bebê" (p.3o); "Recomenda-se que a criança seja amamentada sem restrições de horários e de tempo de permanência na mama. É o que se chama de amamentação em livre demanda” (p. 31). Tais recomendações demonstram a centralidade da criança no processo de amamentação.

Alguns materiais, especialmente o Álbum seriado: promovendo o aleitamento materno (Brasil; Unicef, 2007), utilizam a modalidade denominada por Pinto (1994) como declarativa, caracterizada por "enunciados transparentes, cujos conteúdos são considerados como sendo o próprio universo de referência” (p. 83-84). No entendimento do autor, somente certas pessoas, que ocupam determinadas posições em certas instituições sociais "ganham o direito, o poder e mesmo o dever [...] de produzir enunciados e textos que criam e/ou reproduzem realidade" (p. 83). Tais enunciados, pela legitimidade conferida a quem os emite, tendem a ser reconhecidos como verdadeiros pelos seus receptores, que enxergam neles "a expressão verbal da realidade" (p. 84).

São exemplos dessa utilização, em geral, os enunciados que destacam as vantagens da amamentação, como: "O leite materno dá proteção contra doenças porque só ele tem substâncias que protegem o bebê contra doenças como: diarreia [...], pneumonias, infecção de ouvido, alergias e muitas outras", "Dar de mamar é um ato de amor e carinho", "Dar de mamar ajuda na prevenção de defeitos na oclusão (fechamento) dos dentes, diminui a incidência de cáries e problemas na fala" (BRASIL; Unicef, 2007, p. 4); "A amamentação é importante tanto para a mãe quanto para o bebê" (Unicef; OMS, 2008).

Além de dispensarem a apresentação das evidências que corroboram as informações, eles não levam em consideração possíveis controvérsias com relação às próprias evidências científicas que embasam a política. Com relação ao aleitamento sob livre demanda, como recomendado pela política, por exemplo, Moura, Moura e Toledo (2006) apontam que, após o nascimento dos primeiros dentes, pode 
aumentar a incidência de cáries, e o trabalho de Brew et al. (2012) indica que, embora tenha efeito protetor contra asma, a amamentação prolongada, também preconizada pelo Ministério da Saúde, pode gerar maior risco de sensibilização para alergias alimentares.

\section{Interlocutora ou objeto direto de verbos imperativos?}

A Cartilha para a mãe trabalhadora que amamenta (BRASIL, 2010), material de orientação cujo objetivo é, segundo o MS, "dar algumas respostas" às mães trabalhadoras sobre "como dar de mamar e ao mesmo tempo trabalhar fora de casa", apresenta os direitos da trabalhadora que está amamentando, destaca a importância do aleitamento materno e orienta sobre como proceder para manter a amamentação após o retorno ao trabalho. Nove das suas 24 páginas são destinadas a descrever, em detalhes, o processo de retirada manual do leite e seu oferecimento ao bebê (preparo dos recipientes para coleta, ordenha, acondicionamento, conservação, preparo), destacando a importância do fornecimento do produto - leite materno - à criança por um cuidador quando a mãe estiver impossibilitada de amamentar.

Toda a seção denominada "Por que é importante amamentar” traz afirmações sobre benefícios do aleitamento materno para a criança, a mulher e a família que podem ser classificadas na modalidade declarativa. "O leite materno é o alimento mais completo que existe para o bebê. Nos primeiros seis meses, ele contém tudo que o bebê precisa, até mesmo água!" (p. 10); "Protege o bebê contra muitas doenças, em especial diarreia, pneumonia, otites e outras infecções" (p. 11); "Diminui as possibilidades de surgirem problemas alérgicos, respiratórios e também de algumas doenças que costumam se manifestar mais tarde, tais como obesidade, pressão alta, colesterol alto e diabete" (p. 11); "Diminui as chances de ocorrência do câncer de mama, de ovário e de diabete da mulher que amamenta" (p. 11) são alguns exemplos.

Tais enunciados simulam uma espécie de "transparência da linguagem", buscando se confundir, para o receptor, com a própria "verdade" sobre o tema. É fato que essas afirmativas são, em grande medida, baseadas em pesquisas científicas que apontam a correlação entre o aleitamento materno e essas variáveis (Toma; Rea, 2008). Porém, nem mesmo essas referências são mencionadas no texto, bem como referências que apresentem, na literatura, resultados contraditórios, como os citados anteriormente e outros.

Um bloco de texto, na página 22, inicia com a palavra "atenção" em caixa alta, seguida de um ponto de exclamação, o que induz o leitor a esperar uma informação de máxima importância.

ATENÇÃO! Quando o bebê completa 6 meses ele está pronto para receber alimentos semissólidos. Está na hora de oferecer comida amassada com garfo, e continuar a amamentação. Nesta fase, procure oferecer alimentos saudáveis preparados em casa (em vez de industrializados), em ambiente calmo, mostrando paciência e interesse pelo bebê. E lembre: é recomendável que você continue amamentando até pelo menos os dois anos de idade. (Brasil, 2010, p.22, grifo nosso)

Trata-se de um discurso de "comando", redigido com verbos no tempo presente e, em geral, na forma imperativa, buscando produzir um "efeito de verdade" no discurso. Tal dispositivo, como apontou Pinto (1994), pode ser definido como uma modalização da enunciação conhecida como modalidade diretiva:

Diz-se que um enunciado ou texto apresenta modalidade diretiva se tiver como objetivo tentar que o receptor tenha, no futuro, o comportamento expresso pelo estado de coisas ao qual nele se faz alusão. [...] 0 uso de um enunciado com modalidade diretiva é fortemente dependente das relações de status e familiaridade reconhecidas ou propostas pelo emissor como existentes entre ele e seu interlocutor na situação de comunicação em curso, e o receptor, pela aceitação de seu papel, confirma a validade social delas (Pinto, 1994, p. 92)

Nesse trecho, o emissor alerta a leitora para a necessidade do cumprimento de determinadas 
condições e orientações, materializando o que Verón (2004) chamou de "enunciação pedagógica”, na qual emissor e destinatário da mensagem assumem posições desiguais: "o primeiro mostra, explica, aconselha; o segundo olha, compreende, tira proveito" (Verón, 2004, p. 230) da informação oferecida.

Outros exemplos de modalidade diretiva no texto podem ser observados nos enunciados do quadro "Algumas dicas" da Cartilha (BRASIL, 2010), como "Converse com o patrão para ver a possibilidade de você ter maior flexibilidade nos horários de trabalho", "Fale e explique ao seu patrão e seus colegas a importância de amamentar, explique especialmente que o leite materno protege seu filho", "Explique tudo isso também aos seus familiares” (p. 4), que buscam influenciar a mulher, fazendo-a adotar determinadas atitudes.

No mesmo material, o texto dispensa referências científicas que embasam afirmações sobre as múltiplas vantagens e períodos ideais de aleitamento materno. 0 discurso assume, então, sua tendência a provocar o que Verón (1980, p. 198) chamou de "efeito ideológico" do discurso absoluto, "aquele discurso que se mostra como o único discurso possível acerca daquilo que se fala", ocultando suas condições de produção por meio da naturalização dos sentidos.

Essa característica prescritiva e de mudança de comportamentos dos discursos em prol do aleitamento materno dirigidos às mulheres já havia sido destacada por Meyer (200o) em sua análise do Programa Nacional de Incentivo ao Aleitamento Materno (PNIAM), que deu origem à atual política pública brasileira voltada ao tema. Atuando na perspectiva da consolidação do que a autora nomeou de "uma nova politização do seio e do aleitamento materno", tais discursos, por um lado, retomam alguns dos argumentos utilizados pelo higienismo brasileiro no final do século XIX, como o pressuposto da amamentação como ato natural, biológico e instintivo; por outro lado, empreendem uma ruptura significativa com os saberes que embasavam as prescrições médicas em relação à amamentação que imperavam no país naquele período e durante boa parte do século XX, instituindo, por exemplo, o regime de amamentação denominado de "livre demanda", no qual a mulher deve estar à disposição da criança para amamentá-la quantas vezes e por quanto tempo ela desejar.

De acordo com Meyer (2000), essa espécie de "teia discursiva" que articula, por vezes de forma conflituosa, uma imensa variedade de sentidos e se encontra envolvida em uma trama de poderes e interesses, acaba por produzir corpos e representações de mulher e criança no intuito de garantir a ação universal do aleitamento materno. Para isso, ao mesmo tempo que retoma alguns elementos da retórica sobre o exercício da maternidade produzida nos séculos XVIII e XIX, também "incorpora e ressignifica, enquanto atributos da maternidade e/ ou do leite materno, uma vasta gama de problemas que as sociedades globalizadas produzem e/ou não conseguem resolver" (Meyer, 2000, p. 14).

Ainda na cartilha (BRASIL, 2010), o enunciador dirige sua fala diretamente para a mulher, pelo pronome de tratamento "você". Tal recurso também constitui uma das apresentações da modalidade diretiva, que é a interpelação do interlocutor, ou seja, a chamada do outro para o processo de interlocução. 0 uso do "você" também corresponderia, segundo Pinto (1994), a um enunciado de modalidade expressiva, que visa mostrar "a intenção que o emissor tem de exprimir afetividade ou juízo de valor relativos aos estados de coisas descritos ou a qualquer das entidades participantes" (p. 88). Nesse caso, busca-se, por meio do pronome escolhido, expressar uma informalidade na comunicação e forjar uma intimidade entre emissor e receptor(a) do discurso.

Você, como mãe e trabalhadora remunerada, quer dar ao seu filho o melhor alimento, o contato físico, o carinho, o estímulo, a proteção contra doenças, ou seja, tudo o que você sempre sonhou de melhor. Como você já sabe, amamentar é o que permite dar a seu filho tudo isso. (Brasil, 2010, p. 3, grifos nossos)

Ao afirmar que a mulher a quem se dirige tem determinados desejos ou expectativas em relação ao seu envolvimento com o(a) filho(a), o material pressupõe que ela já detém certo conhecimento que ele procura reafirmar: o de que é por meio da amamentação que a mãe poderá proporcionar ao seu bebê tudo o que foi relacionado: o melhor alimento, 


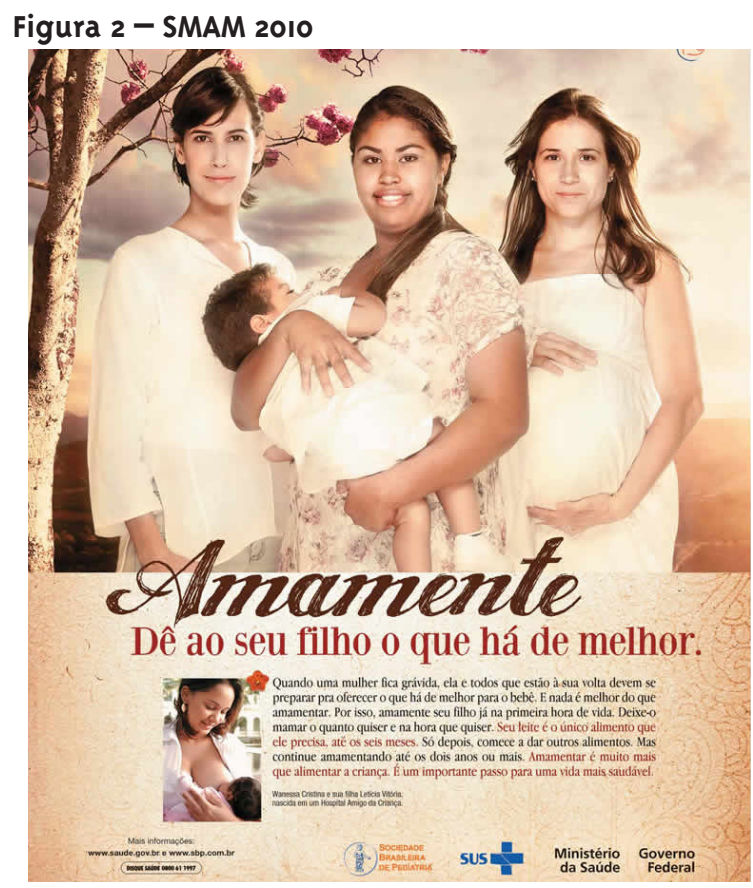

contato físico, carinho, estímulo e proteção contra doenças. E o texto conclui: "Ou seja, tudo o que você sempre sonhou de melhor”. Entendemos que a utilização de tal dispositivo de enunciação constrange a mulher em suas possibilidades de escolha sobre amamentar ou não (no caso, continuar ou não amamentando após o retorno ao trabalho), deixando pouco ou nenhum espaço para a negociação de sentidos entre emissor e receptor do discurso.

Os cartazes das campanhas da SMAM analisados, por sua vez, utilizam largamente de enunciados nas modalidades declarativa e diretiva, como definidas por Pinto (1994). Todos os slogans fazem uso da modalidade declarativa, na qual os enunciados se confundem com a própria "realidade das coisas", conferindo status de verdade ao que é dito. "Amamentação em todos os momentos. Mais saúde, carinho e proteção [subentende-se que para o bebê/criançal" (Figura 1); "Amamente. Dê ao seu filho o que há de melhor" (Figura 2); “Amamentar faz bem para o bebê e para você” (Figura 3, grifos no original); "Amamentar hoje é pensar no futuro" [o texto que vem a seguir deixa claro que, além de contribuir para um futuro com mais saúde para os filhos de quem amamenta, amamentar também é benéfico "para todo Brasil”] (Figura 4); "Tão importante quanto amamentar seu bebê é ter alguém que escute você" (Figura 5).

\section{Figura I - SMAM 2009}

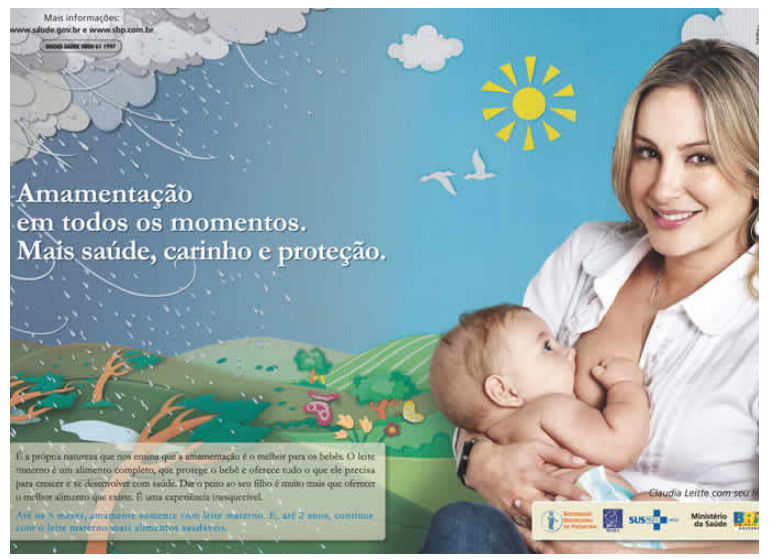

Fonte: Ministério da Saúde

Fonte: Ministério da Saúde

Figura 3-SMAM 2011

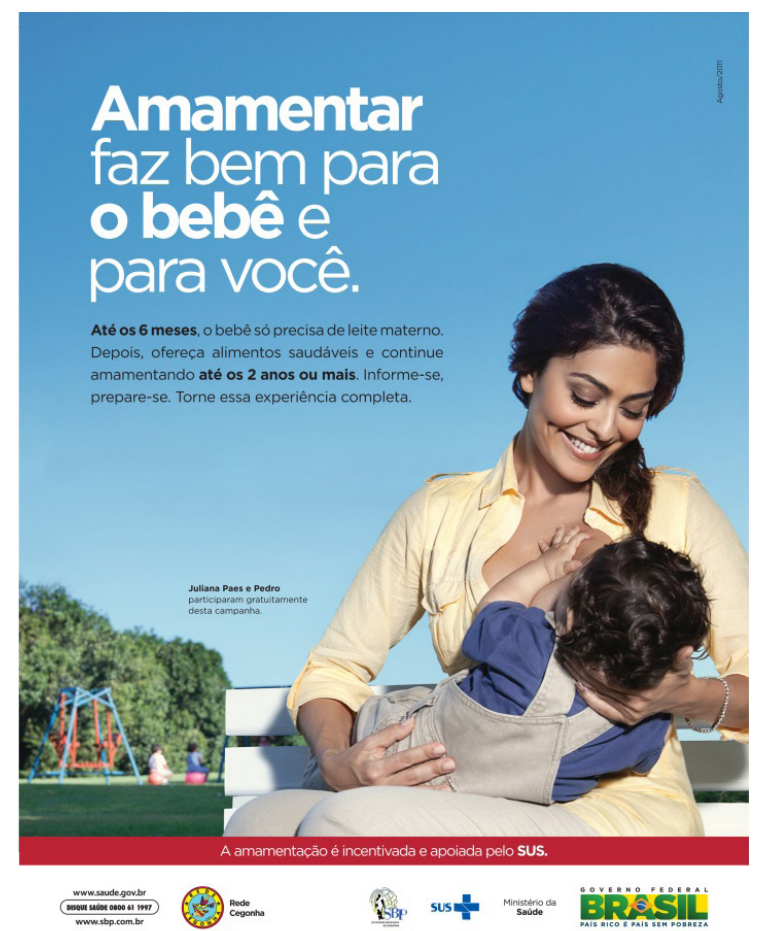

Fonte: Ministério da Saúde 
Figura 4 - SMAM 2012
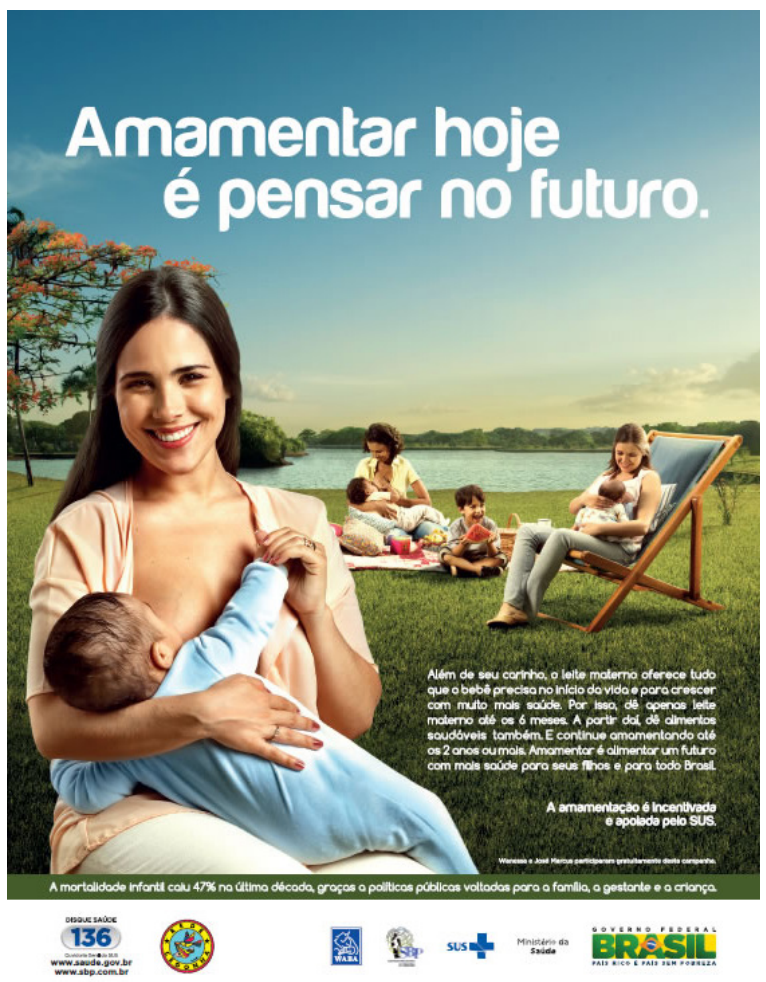

Fonte: Ministério da Saúde

Figura 5- SMAM 2013

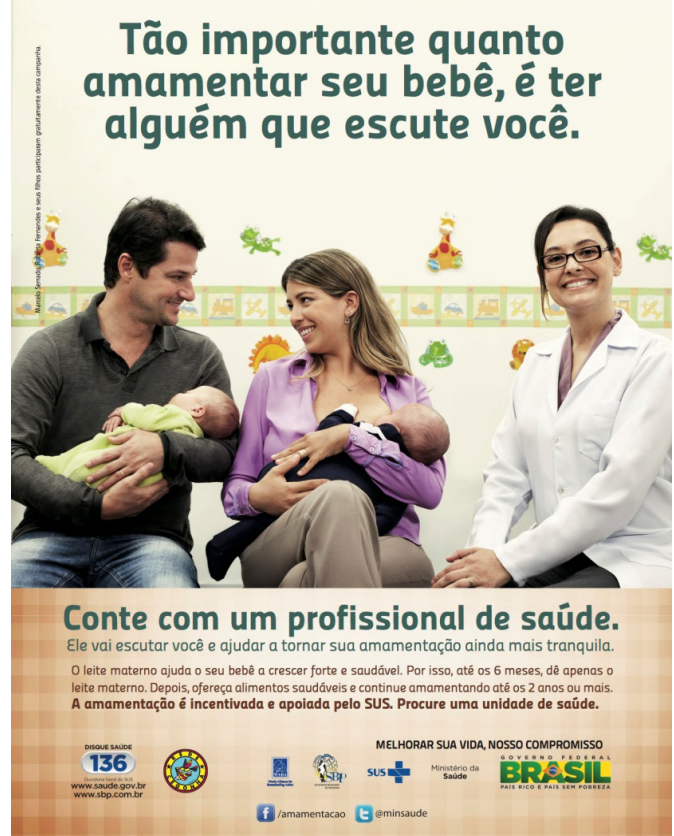

Fonte: Ministério da Saúde
O uso do verbo "ser" no tempo do presente do indicativo em quase todos os enunciados traduz uma declaração inequívoca, assim como as expressões "o que há de melhor" e "amamentar faz bem”. Além do texto que informa a mulher sobre os comportamentos que deve adotar em relação à alimentação e cuidado com a saúde do seu bebê, as campanhas ilustram a perspectiva de que a mãe é um instrumento que torna viável a política pública de redução da morbimortalidade infantil por meio do incremento dos índices de aleitamento materno. A criança é o principal e, na maioria das vezes, único foco dos discursos oficiais proferidos nas campanhas.

O possível distanciamento entre os discursos oficiais e as percepções e vivências maternas da amamentação, como apontado por Kalil, Ferraz e Aguiar (2014) em trabalho sobre a apreciação de um cartaz da SMAM 2010 por mães em fase de amamentação ou com desmame recente, não é, aparentemente, levado em consideração na elaboração dos discursos. Com relação aos períodos ideais de aleitamento, por exemplo, é notável o fato de 5 das 7 mulheres entrevistadas pelos autores discordarem da recomendação do Ministério da Saúde de amamentar até 2 anos de idade ou mais.

As razões apontadas para discordarem dessa orientação estão relacionadas à saúde nutricional e à socialização do bebê; à autonomia e vida social da mãe; à iniciativa da própria criança em desmamar antes da idade expressa na campanha; e a outras formas de reforçar a relação entre mãe e filho que não somente a amamentação (Kalil; Ferraz; Aguiar, 2014, p. 13).

No entanto, já se fazem notar diferenças nos conteúdos dos enunciados. Alguns cartazes mais recentes da SMAM já incluem a mulher - como o sujeito falado ou o "você" do enunciado - na construção dos slogans, destacando a sua importância no processo de amamentação. Em "Amamentar faz bem para o bebê e para você" (Figura 2, grifos no original), a voz autorizada do Ministério da Saúde para afirmar para a gestante e/ou mãe que a prática da amamentação é saudável não somente para o bebê (que está destacado em negrito, juntamente 
com a palavra "amamentar"), mas também para ela. Também no slogan da última campanha, "Tão importante quanto amamentar seu bebêé ter alguém que escute você" (Figura 5), o enunciado se dirige à mulher e ressalta a importância - igual à do próprio ato de amamentar - de ela ser ouvida e apoiada durante o processo de amamentação.

Com relação ao cartaz da SMAM 2013, é interessante observar que ele se destaca, também, por trazer a figura do homem/pai/companheiro para a cena da amamentação. Embora o ator Marcelo Serrado possa ser considerado, de fato, o "padrinho" da campanha (uma vez que sua esposa, Roberta Fernandes, não é tão conhecida pelo grande público), sua presença agrega, aos discursos imagéticos oficiais sobre aleitamento materno, o lugar do pai como apoiador dessa prática junto à mulher, enunciado textual mais comum em outros materiais, como os folders das próprias campanhas da SMAM e manuais voltados aos profissionais de saúde.

Embora se utilizem da modalidade declarativa e da modalidade expressiva, com o uso do pronome "você", que imprime uma informalidade e uma suposta intimidade entre emissor e receptor do discurso, esses cartazes já apresentam enunciados que tentam apresentar a mulher como elemento ativo do processo de amamentação, salientando que se trata de uma prática benéfica também para a saúde da mãe e que ela precisa ser apoiada - seja pela família (representada na imagem pela figura do companheiro), seja pelos serviços de saúde, que têm um papel de destaque no material como fonte de escuta da mulher, capaz de tornar a amamentação “ainda mais tranquila" (Figura 5).

\section{Considerações finais}

A análise dos materiais selecionados revelou que existem diferenças na construção de sentidos sobre a mulher/mãe/lactante. Constitui-se, assim, uma considerável polifonia nos discursos emitidos pelo Ministério da Saúde em diferentes situações enunciativas, ainda que transpareça a centralidade da criança na abordagem sobre amamentação. Em geral, os materiais destinados aos profissionais tendem a falar da mulher como sujeito de crenças, cultura e contextos de vida para além do aleitamento materno, enquanto os materiais destinados às próprias mulheres utilizam, amplamente, uma linguagem que objetifica a mulher no processo de amamentação e desmame, deixando transparecer a ideia de que é seu dever atuar no sentido da conquista da saúde física, mental e emocional de seus filhos. No entanto, isso não acontece de forma homogênea nas publicações.

Os materiais voltados aos profissionais de saúde, por vezes, adotam um discurso mais instrumental em relação ao papel da mulher na amamentação, reproduzindo, quase que de forma literal, o receituário higienista do final do século XIX e início do século XX no Brasil, que, segundo Costa (1999), pregava a relação necessária entre a amamentação e a prova do amor maternal e instituía a ligação da saúde da criança à saúde da nação por meio da amamentação. Isso fica claro, respectivamente, nos enunciados "Dar de mamar é um ato de amor e carinho" (BRASIL; Unicef, 2007, p. 4) e "[O aleitamento materno] Permite ainda um grandioso impacto na promoção da saúde integral da dupla mãe/bebê e regozijo de toda a sociedade" (BRASIL, 2009b, p. 9).

Por outro lado, alguns materiais dirigidos à mulher já começam a destacar seu lugar como sujeito envolvido na prática da amamentação. A mãe deve contar com uma escuta e ser apoiada na experiência de amamentar seu bebê (o que pode ser visto na Figura 5) e, também para ela, a amamentação deve apresentar benefícios que justifiquem sua prática (Figura 3).

Tanto nos textos produzidos para profissionais quanto naqueles feitos para as mulheres é possível perceber uma tensão entre dois sentidos da amamentação: um mais vinculado à questão do fornecimento do leite materno aos bebês, garantindo o que o Ministério da Saúde defende como "alimentação ótima para as crianças pequenas” (BRASIL, 2009a), que é o objetivo maior da política pública; e outro, que apresenta a amamentação como um processo que envolve sujeitos, e, portanto, subjetividades (da mãe, do bebê, do companheiro, de outros filhos etc.) que precisam ser levadas em consideração na concepção dos discursos e das práticas em saúde.

Tal tensão reflete uma disputa social e discursiva que se tem travado com relação à condição da 
mulher nos dias atuais e aos "padrões e experiências contemporâneas de maternidade" (Scavone, 2001, p. 48). Ao mesmo tempo, reflete-se na arena social e discursiva em que as próprias mulheres estão imersas, na qual passam por suas experiências de maternidade, amamentação e todas as demais que são vivenciadas concomitantemente a essas. Meyer (2003) nomeou de "uma nova politização da maternidade" esse processo que tem atuado "ressignificando a relação mãe-filho para inscrever o corpo materno em um poderoso regime de vigilância e regulação" (p. 33). Para a autora, esse processo vem sendo engendrado, em grande medida, pelos discursos e poderes imbricados na constituição dos programas de educação em saúde voltados à população materno-infantil.

Entendemos, como Verón (2004), que a produção dos discursos é a instância de uma proposição de sentidos que podem ou não ser aceitos e, portanto, partilhados pelos receptores. Esse processo, da proposição à apropriação de sentidos, pode ser entendido como uma negociação, na qual emissor e receptor são, na prática discursiva, interlocutores ou coprodutores de sentidos (Araújo; Cardoso, 2007). Por isso mesmo, não acreditamos em um modelo bipolar de comunicação, no qual o receptor é um mero depositário de sentidos definidos previamente pelo emissor do discurso.

Não podemos desconsiderar, no entanto, que os discursos oficiais possuem a força do que Verón (2004, p. 57) chamou de 'discurso absoluto', aquele que carrega uma ilusão de verdade por ocultar suas condições sociais de produção, exercendo uma espécie de 'efeito de poder' sobre seus públicos. Por isso mesmo, defendemos a importância de entender como os materiais oficiais sobre aleitamento materno constituem os objetos de que fala, revelando, ainda, as posições de sujeito e relações que são neles construídas. Tal conhecimento nos auxilia a problematizar discursos que têm desvalorizado, sobretudo nas últimas décadas, as perspectivas e contextos das mulheres no processo de amamentação.

\section{Referências}

ALMEIDA, J. A. G. de. Amamentação: um híbrido natureza-cultura. Rio de Janeiro: Fiocruz, 1999.
ARAÚJO, I. S. de; CARDOSO, J. M. Comunicação e saúde. Rio de Janeiro: Fiocruz, 2007.

BENVENISTE, E. $\mathrm{O}$ aparelho formal da enunciação. In: ______. Problemas de linguística geral I. São Paulo: Pontes, 1989. p. 81-9o.

BRASIL. Ministério da Saúde. Caderno do tutor da Rede Amamenta Brasil. Brasília, DF, 20oga.

BRASIL. Ministério da Saúde. Saúde da criança: nutrição infantil: aleitamento materno e alimentação complementar. Brasília, DF, 20ogb.

BRASIL. Ministério da Saúde. Cartilha para a mãe trabalhadora que amamenta. Brasília, DF, 2010.

BRASIL. Ministério da Saúde. Gestões e gestores de políticas públicas de atenção à saúde da criança: 70 anos de história. Brasília, DF, 2011.

BRASIL; UNICEF. Promovendo o aleitamento materno. Brasília: Ministério da Saúde, 2007 (2. ed.).

BREW, B.K. et al. Breastfeeding, asthma, and allergy: a tale of two cities. Pediatric Allergy and Immunology, Berlin, v. 23, p. 75-82, 2012.

COSTA, J. F. Ordem médica e norma familiar. 4. ed. Rio de Janeiro: Graal, 1999.

FOUCAULT, M. A ordem do discurso. São Paulo: Edições Loyola, 2000 (6. ed.).

FROHMANN, B. O caráter social, material e público da informação. In: FUJITA, M. S. L.; MARTELETO, R. M.; L. M. L. G. de. A dimensão epistemológica da Ciência da Informação e suas interfaces técnicas, políticas e institucionais nos processos de produção, acesso e disseminação da informação. São Paulo: Cultura Acadêmica; Marília: Fundepe, 2008. p. 13-36.

KALIL, I. R.; FERRAZ, L. M. R.; AGUIAR, A. C. de. Da intenção ao gesto: aproximações e distanciamentos entre informações oficiais e percepções maternas sobre amamentação. Diálogos de la Comunicación, Cali, v. 88, p. 1-18, jan./jun. 2014.

MEYER, D. E. Pedagogias do aleitamento materno e produção de identidades de gênero. In: SEMINÁRIOS DE PESQUISA EM EDUCAÇÃO DA REGIÃO SUL - ANPEDSUL, 200o, Porto Alegre. 
Anais... p. 1-17. Disponível em: <http://www. portalanpedsul.com.br/admin/uploads/200o/

Gestao_e_Politicas/Mesa_Redonda_--

Trabalho/o2_01_38_4M3703.pdf>. Acesso em: 11 ago. 2014.

MEYER, D. E. Educação, saúde e modos de inscrever uma forma de maternidade nos corpos femininos. Movimento, Porto Alegre, v. 9, n. 3, p. 33-58, set./ dez. 2003.

MOURA, L. de F. A. de D.; MOURA, M. S. de.; TOLEDO, O. A. Cárie dentária em crianças que frequentaram um programa odontológico de atenção materno-infantil. Journal of Applied Oral Science, Bauru, v. 14, n. 1, p. 53-6o, 2006.

PINTO, M. J. As marcas linguísticas da enunciação: esboço de uma gramática enunciativa do português. Rio de Janeiro: Numen, 1994.
SCAVONE, L. Maternidade: transformações na família e nas relações de gênero. Interface Saúde, Educação, Comunicação, Botucatu, v. 5 , n.8, p.47-6o, 2001.

TOMA, T. S.; REA, M. F. Benefícios da amamentação para a saúde da mulher e da criança: um ensaio sobre as evidências. Cadernos de Saúde Pública, Rio de Janeiro, v. 24, n. 2, p. 23546, 2008.

UNICEF; OMS. Módulo 3 - promovendo e incentivando a amamentação em um Hospital Amigo da Criança: curso de 20 horas para equipes de maternidade. Brasília, DF: Ministério da Saúde, 2008.

VERÓN, E. A produção do sentido. São Paulo: Cultrix, 1980.

VERÓN, E. Fragmentos de um tecido. São Leopoldo: Unisinos, 2004.

\section{Contribuição dos autores}

Kalil redigiu o artigo, que é fruto de sua pesquisa de doutorado, concluída em março de 2015. Aguiar revisou e editou o artigo, na condição de orientadora da pesquisa de doutorado.

Recebido: $11 / 08 / 2014$

Reapresentado: 23/04/2015

Aprovado: 14/08/2015 